\title{
Special Issue on Open Economy Models
}

\author{
Harris Dellas • Patrick Minford
}

This special issue of Open Economies Review consists of revised versions of papers that were presented at a conference held at the Bank of Greece in Athens, on March 27-28, 2009. This issue also contains comments on papers by discussants, and presentations made at the two Policy Panels that took place during the conferenceone on "The banking crisis - causes and cures" and the other on "The euro - can it survive with its present institutions?" The conference on 'Testing Open economy Models' was co-organized by the Bank of Greece, the Julian Hodge Institute of Applied Macroeconomics at Cardiff Business School and the European Monetary Forum, with funding from the Bank of Greece, Cardiff University and the UK Economic and Social Research Council under grant RES-165-25-0020. We are grateful to them for their support, and we thank the conference participants for their contributions.

\footnotetext{
H. Dellas $(\bowtie)$

University of Bern, Berne, Switzerland

e-mail: harris.dellas@vwi.unibe.ch

P. Minford

Cardiff University, Cardiff, Wales, UK
} 